УДК 378.14:372.857

UDC 378.14:372.857

DOI: $10.31475 /$ ped.dys.2020.28.03

ГАЛИНА БІЛЕЦЬКА,

доктор педагогічних наук, доцент

(Україна, Хмельницький, Хмельницький національний університет, вул. Інститутська, 11)

HALYNA BILETSKA,

Doctor of Pedagogical Sciences, Associate Professor (Ukraine, Khmelnytskyi, Khmelnytskyi National University,

Instytutska St., 11)

ORCID: 0000-0002-6299-1853

ОЛЕСЯ МАТЕЮК,

кандидат педагогічних наук, доцент

(Украйна, Хлельницький, Хмельницький національний університет, вул. Інститутська, 11)

Olesia Mateyuk,

Candidate of Pedagogical Sciences, Associate Professor (Ukraine, Khmelnytskyi, Khmelnytskyi National University,

Instytutska St., 11)

ORCID: 0000-0002-0523-7854

\title{
Порівняльний аналіз підготовки майбутніх учителів біології в університетах України і Польщі
}

\section{Comparative Analysis of the Training of Future Biology Teachers at the Universities of Ukraine and Poland}

У статті виявлено особливості підготовки майбутніх вчителів біологї в університетах Украйни і Польщі та обтрунтовано можливості використання прогресивних ідей польського досвіду у вітчизняних закладах вищої освіти. З'ясовано, що профбесійна підготовка вчителів біологї̈ в Польщі передбачае фбундаментальну підготовку з біології доповнену блоком психологопедагогічних дисииллін. Програми педагогічної підготовки складають не менше 25 кредитів ЄКТС. Обгрунтовано, що удосконаленню підготовки майбутніх вчителів біології в Україні буде сприяти впровадження таких прогресивних ідей досвіду польських університетів: поглиблення загальнонаукової підготовки з біології; впровадження міждисииплінарних навчальних курсів та інтегрованих освітніх програл; розширення спектру психолого-педагогічних дисциплін; збільшення обсягу практичної підготовки, проведення педагогічних практик впродовж семестру; збільшення частки науково-дослідницької роботи здобувачів магістерського рівня вищої освіти; розширення програл міжнародного обміну учасників освітнього процесу.

Ключові слова: вища освіта; майбутні вчителі біологї; освітня програма; навчальний план.

The features of future biology teachers training at the universities of Ukraine and Poland are revealed in the article and the possibility of using the progressive ideas of the Polish experience in domestic higher education institutions is substantiated. As a result of studying educational programs and curricula, common features and differences in the professional training of biology teachers in Poland and Ukraine were identified. It has been found that the training of future biology teachers in Poland involves a fundamental biology training supplemented by a block of psychology and pedagogical disciplines. It has been found out that pedagogical training programs for future biology teachers at Polish universities are at least 25 ECTS credits and contain a significant list of academic disciplines that provide comprehensive and thorough training in pedagogical activities. It has been found out that Polish universities offer ample opportunities for the mobility of educational participants. It is substantiated that the improvement of training of future biology teachers in Ukraine will be facilitated by the implementation of the following progressive ideas of the experience of Polish universities: deepening general science training in biology, which will increase the employment opportunities for graduates; introduction of interdisciplinary training courses and integrated educational programs, which will broaden the range of subjects that the teacher can teach in general education institutions; 
reflection in the content of the disciplines of professional training of modern achievements of natural sciences and tendencies of their development, global problems of modernity and ways of their solution; introduction in preparation of future teachers of biology of psycho-pedagogical disciplines, the content of which reflects the current tendencies in education and the requirements of society for pedagogical staff; increasing the amount of practical training, conducting pedagogical practices throughout the semester, which will ensure the systematic practical training; an increase in the share of research work for the masters of higher education; expanding the international exchange of participants in the educational process.

Key words: higher education; future biology teachers; educational program; curriculum.

Вступ / Introduction. Входження України в европейський освітянський простір зумовило радикальні зміни у системі вищої освіти. 3 урахуванням евроінтеграційних процесів 2014 р. був прийнятий Закон України «Про вищу освіту», який містить багато норм, апробованих в європейських університетах, але нових для українських закладів вищої освіти. Це зумовлює науковий інтерес до вивчення досвіду вищої освіти країн Європейського Союзу.

В умовах реформування освіти України одним із пріоритетних завдань е забезпечення якісної професійної підготовки вчителів. Цікавим і корисним для української системи вищої педагогічної освіти е досвід Республіки Польща. Це зумовлено тим, що Польща і Україна мають багато спільного в культурному, соціально-історичному розвитку. Крім того, Польща як член Європейського Союзу вже здійснила реформи у галузі вищої освіти. Необхідність впровадження прогресивного европейського досвіду в професійну підготовку вчителів у закладах вищої освіти України зумовлюе актуальність дослідження.

Мета та завдання / Aim and Tasks. Метою дослідження є виявлення особливостей підготовки майбутніх вчителів біології в університетах України і Польщі та обгрунтування можливостей використання прогресивних ідей польського досвіду у вітчизняних закладах вищої освіти.

Методи / Methods. Для досягнення мети дослідження використовувалися такі методи дослідження: аналіз, синтез, узагальнення для вивчення освітніх програм і навчальних планів підготовки майбутніх вчителів біології в Україні і Польщі; компаративний - для виявлення подібних і відмінних підходів до професійної підготовки вчителів біології в Україні і Польщі; прогностичний - для обгрунтування шляхів використання прогресивних ідей польського досвіду професійної підготовки майбутніх вчителів біології в Україні.

Для визначення особливостей підготовки майбутніх вчителів біології в Україні і Польщі вивчено освітні програми i навчальні плани українських університетів (Тернопільський національний педагогічний університет імені Володимира Гнатюка, Дрогобицький державний педагогічний університет імені Івана Франка, Харківський національний університет імені В.Н. Каразіна, Хмельницький національний університет, Херсонський державний університет) i польських університетів (Ягелонський університет (м. Краків), Університет імені Марії КюріСклодовської в Любліні, Вроцлавський університет, Гданський університет, Педагогічний університет ім. Комісії народної освіти в Кракові).

Результати / Results. Підготовка майбутніх вчителів біології в університетах України і Польщі здійснюеться на першому (бакалаврському) і другому (магістерському) рівнях вищої освіти. Успішне виконання особою освітньої програми на першому рівні $е$ підставою для присудження їй ступеня вищої освіти «бакалавр», на другому рівні - ступеня «магістр». Особа має право здобувати ступінь бакалавра за умови наявності у неї повної загальної середньої освіти, ступінь магістра - за умови наявності ступеня бакалавр.

Професійна підготовка вчителів біології в Україні здійснюеться у педагогічних закладах вищої освіти і класичних університетах. Навчання здійснюеться за денною і заочною формами навчання. Обсяг освітніх програм для першого (бакалаврського) рівня вищої освіти складае 240 кредитів ЄКТС. Ступінь магістра здобувається за освітньо-професійною або освітньо-науковою програмою. Обсяг освітньо-професійної програми підготовки магістра становить 90 кредитів ЄКТС, освітньонаукової програми - 120 кредитів СКТС. Освітньо-наукова програма магістра обов'язково включає дослідницьку (наукову) компоненту обсягом не менше 30 \% (Закон України, 2014). Нормативна тривалість навчання за освітніми програмами визначаеться в академічних роках. Освітня програма бакалавра за денною формою навчання розрахована на 4 роки. Тривалість навчання бакалавра за заочною формою може перевищувати термін навчання за денною формою не більше ніж на $25 \%$. Тривалість навчання магістра за денною і заочною формами навчання становить півтора роки у випадку освітньо-професійної програми і два роки у випадку освітньо-наукової програми. Для рівнів вищої освіти бакалавра і магістра навчальне навантаження на академічний рік складае 60 кредитів СКТС (Наказ Міністерства освіти і науки, 2015). Випускники, що мають 
ступінь бакалавра можуть працювати на посадах вчителя або асистента вчителя середнього навчально-виховного закладу, організатора або методиста дитячого позашкільного закладу. Випускники, що мають ступінь магістра, за умови виконання освітньо-наукової програми, крім вище зазначених посад, також можуть працювати викладачами закладів передвищої і вищої освіти (Класифікатор професій, 2010).

Підготовка вчителів в Україні відповідно до Постанови Кабінету Міністрів України № 266 від 29.04.2015 р. (Постанова Кабінету Міністрів України, 2015) здійснюеться за спеціальністю «014 Середня освіта (за предметними спеціальностями)», що відноситься до галузі 01 Освіта/Педагогіка. Предметні спеціальності цієї спеціальності визначені наказом Міністерства освіти і науки України № 506 від 31 травня 2016 року (Наказ Міністерства освіти і науки України, 2016). Професійна підготовка вчителів біології здійснюеться за предметною спеціальністю «014.05 Середня освіта (Біологія та здоров’я людини)». Успішне виконання особою освітньої програми е підставою для присвоення кваліфікації «вчитель біології та здоров'я людини». Вищі навчальні заклади також можуть розробляти та акредитувати інтегровані освітні програми, що надають можливість здійснювати підготовку за двома предметними спеціальностями i присвоювати додаткову кваліфікацію.

Стандарти вищої освіти для спеціальності 014 Середня освіта допоки що не затверджені. Це, 3 одного боку, надає закладам вищої освіти змогу самостійно розробляти освітні програми підготовки здобувачів вищої освіти з урахуванням специфіки закладу освіти і потреб ринку праці. I іншого боку, автономність у розробленні освітніх програм ставить серйозні виклики перед університетською спільнотою, адже зміст освітніх компонентів програми має забезпечувати якість вищої освіти на інституційному рівні.

Навчальні плани підготовки майбутніх вчителів біології на бакалаврському і магістерському рівнях вищої освіти складаються з двох частин - обов’язкової та вибіркової. Максимальний обсяг обов'язкової частини навчального плану може становити $75 \%$ від загального обсягу (Наказ Міністерства освіти і науки, 2015). Освітні компоненти (дисципліни) обов'язкової частини навчального плану мають забезпечувати формування компетентностей, визначених освітньою програмою. Мінімальний обсяг вибіркової частини навчального плану має становити не менше 25 \% (Наказ Міністерства освіти і науки, 2015). Каталоги вибіркових дисциплін розміщені на сайтах закладів вищої освіти, що забезпечуе прозорість освітнього процесу i реалізацію індивідуальної освітньої траєкторії студентів.

Навчальні плани підготовки майбутніх вчителів біології містять дисципліни, що відображають зміст різних біологічних наук («Ботаніка», «Фізіологія рослин», «Біогеографрія», «Зоологія», «Анатомія людини», «Фізіологія людини і тварин», «Мікробіологія», «Цитологія», «Гістологія», «Біологія індивідуального розвитку», «Генетика», «Молекулярна біологія» та ін.) і дисциплін психолого-педагогічної підготовки («Психологія», «Психофізіологія шкільного віку», «Педагогіка», «Методика навчання біології», «Методика навчання основ здоров'я», «Освітні технології», «Інформаційні технології в освіті», «Еколого-натуралістична діяльність школярів» та ін.). Оскільки підготовка майбутніх вчителів біології здійснюеться за предметною спеціальністю біологія та здоров'я людини, навчальні плани також містять дисципліни, що забезпечують підготовку до викладання основ здоров’я у загальноосвітній школі («Загальна теорія здоров’я», «Основи здорового способу життя», «Психологія здоров'я та здорового способу життя», «Соціальні та моральні основи здоров'я», «Методика навчання основ здоров'я» та ін.).

Необхідним компонентом підготовки майбутніх вчителів біології е практики, які проводяться у відведений на них час або впродовж семестру. Обсяг практичної підготовки визначае випускова кафедра. На педагогічні практики рекомендовано відводити не менше 12 кредитів СКТС.

У багатьох педагогічних університетах розроблені інтегровані освітні програми підготовки майбутніх вчителів біології. Наприклад, у Тернопільському національному педагогічному університеті імені Володимира Гнатюка і Дрогобицькому державному педагогічному університеті імені Івана Франка реалізуються інтегровані освітні програми, що дозволяють присвоювати випускникам додаткову кваліфікацію «вчитель хімії». Навчальними планами підготовки майбутніх вчителів біології у цих закладах вищої освіти передбачено низку дисциплін, що забезпечують фундаментальну підготовку 3 хімії («Загальна хімія», «Неорганічна хімія», «Органічна хімія», «Фізична і колоїдна хімія», «Аналітична хімія», «Біохімія»), а також дисципліна «Методика навчання хімії».

Варто зазначити, що у багатьох закладах вищої освіти України здійснюється екологічна освіта майбутніх вчителів біології (Тернопільський національний педагогічний університет імені Володимира Гнатюка, Харківський національний університет імені В.Н. Каразіна, Хмельницький національний університет). Навчальні плани підготовки бакалаврів у цих університетах містять такі дисципліни як «Загальна екологія», «Екологія рослин», «Екологія тварин», «Екологія людини», 
«Охорона біотичного і ландшафтного різноманіття», «Екологія і раціональне використання ресурсів» та ін. Здобувачі вищої освіти на магістерському рівні вивчають дисципліни «Екологічні проблеми сучасності», «Екологічний моніторинг», «Проблеми природокористування», «Стратегія сталого розвитку» та ін.

Атестація випускників освітніх програм за спеціальністю «014.05 Середня освіта (Біологія і здоров'я людини)» на першому (бакалаврському) рівні вищої освіти здійснюеться у формі кваліфікаційного екзамену, який е комплексним і включае завдання з педагогіки, психології, різних розділів біології, основ здоров’я людини, методик навчання біології і здоров'я людини в загальноосвітній школі. На другому (магістерському) рівні атестація випускників здійснюеться або у вигляді кваліфікаційного екзамену, або дипломної роботи магістра.

Підготовка майбутніх вчителів біології в Польщі здійснюеться переважно в класичних університетах, а також в деяких педагогічних університетах (більшість польських педагогічних університетів забезпечують підготовку здобувачів вищої освіти за такими спеціальностями як дошкільна освіта, початкова шкільна освіта, спеціальні педагогіка, соціальна робота, психологія). Навчання здійснюеться за денною, заочною і вечірньою формами навчання.

Професійна підготовка вчителів біології в Польщі передбачае фрундаментальну підготовку 3 біології доповнену блоком психолого-педагогічних дисциплін. $\mathrm{y}$ переважній більшості університетів здобувачі вищої освіти, що мають намір працювати вчителями біології, навчаються за спеціальністю «Біологія», іноді за іншими біологічними спеціальностями (наприклад, «Генетика», «Біотехнологія» та ін.).

У Польщі тривалість навчання на першому (бакалаврському) рівні вищої освіти складае 3 роки, на другому (магістерському) рівні - 2 роки. Обсяг освітніх програм для першого рівня вищої освіти складає 180 кредитів СКТС, для другого рівня - 120 кредитів СКТС. Обов'язкова частина навчальних планів підготовки майбутніх вчителів біології складае не менше $50 \%$ на бакалаврському рівні i не менше $25 \%$ на магістерському рівні. Вибіркові дисципліни пропонуються студентам у вигляді каталогу вибіркових дисциплін, а на старших курсах ще й як блоки дисциплін різних спеціалізацій. Тривалість практичної підготовки дуже варіюе у різних університетах. Підготовка до педагогічної діяльності може здійснювати, як на першому (бакалаврському) рівні вищої освіти, так і на другому (магістерському) рівні. Програма педагогічної підготовки складає не менше 25 кредитів СКТС.

У багатьох університетах Польщі студенти на старших курсах можуть обрати спеціалізацію в межах спеціальності. Наприклад, в Університеті імені Марії Кюрі-Склодовської в Любліні у четвертому семестрі пропонуються на вибір такі спеціалізації: біохімія, мікробіологія, експериментальна біологія, біоаналітика, медична біологія. У Вроцлавському університеті здобувачі вищої освіти можуть оборати спеціалізації мікробіологія, генетика та експериментальна біологія, біологія людини. У Гданському університеті студентам на вибір пропонуються спеціалізації молекулярна і клітинна біологія, біотехнологія, біологія рослин, біологія тварин, біологія людини, екологія.

Атестація випускників університетів Польщі першого (бакалаврського) рівня вищої освіти здійснюеться у вигляді атестаційного екзамену або захисту дипломної роботи бакалавра, другого (магістерського) рівня вищої освіти - у вигляді захисту дипломної роботи магістра (магістерської дисертації).

Для визначення особливостей підготовки майбутніх вчителів біології в Польщі та обгрунтування шляхів використання прогресивних ідей досвіду цієї країни у закладах вищої освіти України розглянемо детальніше освітні програми і навчальні плани польських університетів.

У Ягелонському університеті (м. Краків) підготовка вчителів біології здійснюеться на біологічному факультеті за спеціальністю «Біологія». Програмою навчання передбачено вивчення різних розділів біології, а також цілої низки екологічних дисциплін («Біосферне різноманіття», «Екологічний моніторинг», «Екологія та охорона природи», «Основи сталого розвитку» та ін.). Студенти, зацікавлені отримати право викладати біологію у закладах середньої освіти, можуть обрати курс педагогічної підготовки на першому або другому рівні вищої освіти. Програма педагогічної підготовки містить 25 кредитів ЄКТС (вчитель біології у середній школі) або 35 кредитів СКТС (вчитель біології у середній школі і природознавства у початковій школі). Також студенти проходять педагогічну практику у Педагогічному коледжі Ягелонського університету. На практичну педагогічну підготовку відводиться від 4 до 7 тижнів, що складає від 6 до 11 кредитів.

В Університеті імені Марії Кюрі-Склодовської в Любліні підготовку вчителів біології здійснює факультет біології і біотехнології за спеціальностями «Біологія» і «Біотехнологія». Педагогічну освіту, що надає право викладати біологію в середній школі і природознавство у початковій школі, можна здобути на магістерському рівні освіти. Програма педагогічної підготовки містить 37 кредитів ЄКТС, з них 7 кредитів СКТС - практична підготовка. Варто зазначити, що студенти 
факультету мають можливість брати участь у трьохмісячній науковій практиці в США в Університеті Айдахо.

У Вроцлавському університеті професію вчителя біології можна здобути на біологічному фракультеті навчаючись за спеціальностями «Біологія», «Мікробіологія», «Генетика та експериментальна біологія», «Біологія людини». Освітня програма передбачає фундаментальну підготовку не лише з біології, а й інших природничих дисциплін. Студенти вивчають дисципліни «Хімія для біології», «Фізика з елементами біофізики», «Математика для біології», «Екологія». Підготовка до педагогічної професії здійснюеться впродовж двох років навчання на бакалаврському рівні. Програма педагогічної підготовки складає 30 кредитів ЄКТС, з них 7 кредитів - практична підготовка.

У Гданському університеті підготовку майбутніх вчителів біології здійснюе біологічний факультет за спеціальністю «Біологія». Для здобувачів вищої освіти, які мають намір отримати професію вчителя в університеті розроблено програму педагогічної підготовки, якою у кожному семестрі навчання передбачені дисципліни педагогічної, психологічної і дидактичної підготовки. Обсяг програми педагогічної підготовки складае 25 кредитів ЄКТС, з них 6 кредитів ЄКТС практична підготовка.

В Педагогічному університеті ім. Комісії народної освіти в Кракові підготовка майбутніх вчителів біології здійснюеться на факультеті географії і біології. Студенти, так само як і в класичних університетах, навчаються за спеціальністю «Біологія» і вивчають блок психологопедагогічних дисциплін. Підготовка до педагогічної діяльності здійснюється два рази в тиждень у вечірній час. Практична підготовка передбачає психолого-педагогічну і дидактичну практики, які проводяться впродовж семестру.

Випускники університетів Польщі, які мають фундаментальну підготовку з біології, вивчили блок психолого-педагогічних дисциплін і мають диплом бакалавра, мають право викладати біологію або біологію і природознавство в середніх школах і ліцеях. Випускники з дипломом магістра мають можуть викладати ці предмети у будь-якому типі шкіл (Laska, 2007). Варто зазначити, що в Польщі до претендента на посаду вчителя висуваються вимоги стосовно кваліфікації, моральних характеристик і здоров’я. Ці вимоги регламентуе Карта вчителя (Karta nauczyciela, 2008), у якій зазначається, що посаду вчителя може обіймати особа, яка має вищу освіту з відповідною педагогічною підготовкою або закінчила установу, що здійснюе підготовку вчителів і має досвід роботи на відповідній посаді, дотримуеться моральних принципів і за станом здоров’я здатна виконувати професійні обов'язки (Karta nauczyciela, 2008).

Аналіз освітніх програм підготовки майбутніх вчителів біології в університетах України i Польщі дозволив порівняти вимоги до випускників, сформульовані в у вигляді компетентностей. В освітніх програмах підготовки здобувачів вищої освіти в Україні використовуеться загальноприйнятий поділ компетентностей на інтегральну, загальні і фахові компетентності. Інтегральна компетентність - це узагальнений опис кваліфікаційного рівня відповідно до Національної рамки кваліфікацій, який виражає основні компетентністні характеристики рівня щодо навчання та/або професійної діяльності. Загальні компетентності мають універсальний, не прив'язаний до предметної галузі характер. Вони важливі для подальшої успішної професійної і соціальної діяльності випускників та їх собистісного розвитку. Фахові компетентності залежать від предметної галузі та необхідні для успішної професійної діяльності за певною спеціальністю. Ці компетентності визначають профіль освітньої програми і кваліфікацію випускника, роблять кожну освітню програму особливою (Кремень, 2014).

Переліки компетентностей в освітніх програмах підготовки бакалаврів за спеціальністю «014.05 Середня освіта (Біологія і здоров'я людини)» містять 10-12 загальних компетентностей i 14-20 фахових. До загальних відносяться компетентності, що забезпечують здатність реалізувати особистістю свої права і обов'язки як члена суспільства; здатність зберігати і примножувати моральні, культурні і наукові цінності та досягнення суспільства; здатність до самоосвіти; здатність працювати в команді; здатність спілкуватися державною та іноземною мовою; здатність використовувати інформаційні і комунікаційні технології; здатність адаптуватися до мінливих умов професійного середовища та суспільного життя, діяти на основі етичних міркувань.

Переважна більшість фахових компетентностей здобувачів вищої освіти за спеціальністю «014.05 Середня освіта (Біологія і здоров’я людини)» на першому (бакалаврському) рівні вищої освіти стосуються їх здатності до педагогічної діяльності: володіння основами цілепокладання, планування і проектування освітнього процесу; здатність застосовувати методи і засоби навчання біології та основ здоров'я людини; здатність реалізувати міжмпедметні зв'язки; здатність здійснювати об'єктивний контроль та оцінювання навчальних досягнень учнів; здатність здійснювати виховання на уроках і в позакласній роботі; здатність до критичного аналізу і корекції власної педагогічної діяльності; здатність розуміти і пояснювати будову, функції, класифікацію, 
походження, поширення, використання живих організмів і систем усіх рівнів організації; здатність формувати в учнів розуміння цілісності і взаємозалежності живих організмів; здатність фрормувати в учнів позитивну мотивацію до здорового способу життя; здатність здійснювати безпечні біологічні дослідження в лабораторії і природних умовах, інтерпретувати результати досліджень.

Магістерські програми підготовки майбутніх вчителів біології в Україні спрямовані на формування здатності здійснення інноваційної та дослідницької діяльності у галузі освіти i біології. Крім перелічених вище компетентностей, магістр середньої освіти за предметною спеціальністю біологія та здоров'я людини повинен бути здатним розв'язувати складні комплексні задачі, що потребують інтеграції природничих та фрілософрсько-природничих знань; володіти методами наукового пошуку; вміти планувати й організовувати педагогічні i біологічні дослідження, презентувати наукові здобутки; бути здатним здійснювати управлінську діяльність (на рівні керівника методичного об’еднання, завуча або директора закладу освіти).

Аналіз переліків компетентностей в освітніх програмах, за якими здійснюеться підготовка бакалаврів за спеціальністю «Біологія» та іншими біологічними спеціальностями в польських університетах, дозволив зробити такі узагальнення:

- переліки компетентностей випускників значно менші, але компетентності сформульовані ширше. Відсутній поділ на загальні і фрахові компетентності;

- переважна більшість компетентностей описують вимоги до біологічної підготовки та особистісного розвитку випускників: володіння знаннями з біології; здатність використовувати отриманні знання і навички у професійній діяльності; володіння сучасними інструментальними та аналітичними методами лабораторних i польових досліджень; знання правил безпечного поводження 3 реактивами та апаратурою; здатність виконувати дослідження біологічного матеріалу, описувати та інтерпретувати отримані результати за допомогою методів математичної статистики; здатність здійснювати пошук та обробку інформації, надавати інформацію письмовій та усній формі; володіння іноземною мовою на рівні В2, здатність використовувати біологічну термінологію іноземною мовою; здатність дотримуватися правових та етичних принципів; володіння навичками командної роботи; здатність адаптуватися до вимог ринку праці; здатність самостійно підвищувати свій освітній рівень; готовність до освіти на другому рівні вищої освіти в галузі біологї;

- у переліках лише одна-дві компетентності стосуються здатності працювати у галузі освіти.

Освітні програми магістерського рівня вищої освіти спрямовані на поглиблення знань i навичок, отриманих під час навчання на бакалаврському рівні. Крім того підготовка магістрів має більш вузьку спеціалізацію. Як правило більше 50 \% занять - це робота над дослідницьким проектом, яку студенти проводять в групах під керівництвом викладача. Ці дослідження $€$ частиною магістерської дисертації. Випускники, що завершили навчання на другому (магістерському) рівні вищої освіти за спеціальністю біологія, крім перелічених вище компетентностей, повинні бути здатними здійснювати науково-дослідну роботу i управляти командною роботою.

Обговорення / Discussion. В результаті порівняльного аналізу визначено спільні і відміні підходи до підготовки майбутніх вчителів біології в університетах України і Польщі (табл. 1).

Основна відмінність у професійній підготовщі вчителів біології в Україні і Польщі полягає в тому, що студенти польських університетах отримують фрундаментальну підготовку за спеціальністю біологія і можуть працювати не лише вчителем, а й займати відповідні посади у науково-дослідних установах і лабораторіях; національних і ландшафтних парках, ботанічних i зоологічних садах; центрах розведення рослин і тварин; санітарно-епідеміологічних станціях; установах, що займаються охороною навколишнього природного середовища; органах державного і місцевого управління. Це суттево розширюе можливості працевлаштування випускників. Крім того, фундаментальна природничо-наукова підготовка студентів за спеціальністю біологія у польських університетах забезпечує формування інтегрованих знань і здатності вирішувати міждисциплінарні завдання під час профресійної діяльності.

Варто зазначити, що в Україні з 2006 до 2015 року підготовка вчителів біологї здійснювалася так само, як в польських університетах, тобто передбачала фрундаментальну підготовку з біології. У переліках напрямів і спеціальностей підготовки здобувачів вищої освіти, не було напряму чи спеціальності середня освіта. Біологія (так само як хімія, геоградрія, геологія та екологія) відносилася до галузі знань природничі науки. Переліки напрямів і спеціальностей підготовки містили примітки, що вказували за якими напрямами чи спеціальностями здійснювалася підготовка фрахівців з присвоенням кваліфікації вчителя або викладача закладу вищої освіти, за умови виконання психолого-педагогічної, методичної і практичної програм підготовки. 


\begin{tabular}{|c|c|c|c|c|}
\hline \multicolumn{5}{|c|}{$\begin{array}{c}\text { Порівняльна таблиця особливостей підготовки майбутніх учителів біології } \\
\text { в університетах України і Польщі }\end{array}$} \\
\hline \multirow[t]{2}{*}{ Критерій } & \multicolumn{2}{|c|}{ Україна } & \multicolumn{2}{|c|}{ Польща } \\
\hline & бакалавр & магістр & бакалавр & магістр \\
\hline $\begin{array}{l}\text { Тривалість } \\
\text { навчання }\end{array}$ & $\begin{array}{c}4 \text { роки (денна } \\
\text { форма навчання) i } \\
5 \text { років (заочна } \\
\text { фрорма) } \\
\end{array}$ & 1,5-2 роки & 3 роки & 2 роки \\
\hline $\begin{array}{l}\text { Форми } \\
\text { навчання }\end{array}$ & \multicolumn{2}{|c|}{ Денна, заочна } & \multicolumn{2}{|c|}{ Денна, заочна, вечірня } \\
\hline \multirow{2}{*}{$\begin{array}{l}\text { Кількість } \\
\text { кредитів ЄКТС }\end{array}$} & \multirow[t]{2}{*}{240} & \multirow[t]{2}{*}{$90-120$} & 180 & 120 \\
\hline & & & \multicolumn{2}{|c|}{$\begin{array}{l}\text { додатково не менше } 25 \text { кредитів СКТС } \\
\text { педагогічна підготовка }\end{array}$} \\
\hline $\begin{array}{l}\text { Особливості } \\
\text { програми }\end{array}$ & \multicolumn{2}{|c|}{$\begin{array}{l}\text { Залежить від особливостей закладу } \\
\text { вищої освіти і регіональних потреб } \\
\text { ринку праці }\end{array}$} & \multicolumn{2}{|c|}{$\begin{array}{l}\text { На старших курсах навчання можна } \\
\text { обрати } \quad \text { вузьку спеціалізацію, } \\
\text { підготовка за спеціальністю часто } \\
\text { поєднується з екологічною освітою }\end{array}$} \\
\hline $\begin{array}{l}\text { Мобільність } \\
\text { студентів } \\
\text { викладачів } \\
\end{array}$ & \multicolumn{2}{|c|}{$\begin{array}{lc}\text { Здійснюеться } & \text { за індивідуальними } \\
\text { договорами } & \text { учасників } \\
\text { процесу } & \end{array}$} & \multicolumn{2}{|c|}{$\begin{array}{l}\text { Широкі можливості для мобільності } \\
\text { учасників освітнього процесу }\end{array}$} \\
\hline $\begin{array}{l}\text { Підсумкова } \\
\text { атестація }\end{array}$ & $\begin{array}{l}\text { Кваліфікаційний } \\
\text { екзамен }\end{array}$ & $\begin{array}{lr}\text { Кваліфрікаційний } \\
\text { екзамен } \\
\text { дипломна } \\
\text { магістра }\end{array}$ & $\begin{array}{lr}\text { Атестаційний } \\
\text { екзамен } \\
\text { дипломна робо } \\
\text { бакалавра }\end{array}$ & $\begin{array}{l}\text { Дипломна робота } \\
\text { магістра } \\
\text { (магістерська } \\
\text { дисертація) }\end{array}$ \\
\hline $\begin{array}{l}\text { Придатність } \\
\text { до п праце- } \\
\text { влаштування }\end{array}$ & $\begin{array}{lr}\text { Вчитель } & / \\
\text { асистент вчителя } \\
\text { середнього } \\
\text { навчально- } \\
\text { виховного } \\
\text { закладу, } \\
\text { організатор } \\
\text { методист } \\
\text { шкільного поза- } \\
\text { закладу } \\
\end{array}$ & $\begin{array}{l}\text { Вчитель } \\
\text { середнього } \\
\text { навчально- } \\
\text { виховного } \\
\text { закладу, } \\
\text { викладач закладу } \\
\text { передвищої } \\
\text { вищої освіти }\end{array}$ & $\begin{array}{l}\text { Вчитель середньої } \\
\text { школи }\end{array}$ & $\begin{array}{l}\text { Вчитель будь- } \\
\text { якого типу школи }\end{array}$ \\
\hline
\end{tabular}

Наступна відмінність полягае в тому, що програмами психолого-педагогічної підготовки майбутніх вчителів біології в польських університетах передбачено значно ширший перелік навчальних дисциплін, ніж в українських. Це дисципліни, що відображають зміст різних підрозділів педагогіки, психології, а також такі дисципліни як «Робота з учнями з особливими потребами», «Риторика», «Методика експериментальної роботи в школі», «Безпека в школі», «Уроки на природі» та ін. Вивчення цих дисциплін студентами забезпечуе всебічну і грунтовну підготовку до педагогічної діяльності у непередбачуваних умовах освітнього процесу закладів середньої освіти.

Ще одна відмінність у підготовці майбутніх вчителів біології в Україні і Польщі полягає в тому, що польські університети надають широкі можливості для мобільності учасників освітнього процесу. Значною мірою це зумовлено тим, що студенти отримують фундаментальну підготовку 3 біології, яку поглиблюють в університетах інших країн чи Польщі, що мають потужні дослідницькі лабораторії або спеціалізуються на підготовці вузькоспеціалізованих фрахівців у галузі біології. В університетах України мобільність учасників освітнього процесу здійснюеться переважно за індивідуальними договорами. Окремі заклади вищої освіти пропонують здобувачам магістерського рівня вищої освіти участь у програмі подвійного дипломування та закордонного стажування.

Висновки / Conclusions. Узагальнення результатів дослідження уможливило запропонувати такі рекомендації щодо використання прогресивних ідей досвіду університетів Польщі для удосконалення підготовки майбутніх вчителів біології в Україні:

- поглиблення загальнонаукової підготовки з біології, що дозволить випускникам за спеціальністю Середня освіта (Біологія та здоров'я людини) працевлаштовуватися у біологічні i санітарно-епідеміологічні лабораторії, природоохоронні установи, центри розведення рослин i тварин тощо; 
- впровадження міждисциплінарних навчальних курсів та інтегрованих освітніх програм підготовки майбутніх вчителів біології, що розширить спектр навчальних предметів, які педагог може викладати у загальноосвітніх закладах;

- відображення у змісті дисциплін професійної підготовки сучасних досягнень природничих наук і тенденції ї розвитку, глобальних проблем сучасності і способів раціонального використання природних ресурсів та охорони довкілля;

- збільшення обсягу педагогічних практик, здійснення практичної підготовки впродовж семестру, що забезпечить їі систематичність;

- впровадження у підготовку майбутніх вчителів біології психолого-педагогічних дисциплін, зміст яких відображае сучасні тенденції в освіті та вимоги суспільства до педагогічних кадрів;

- збільшення частки науково-дослідницької роботи здобувачів магістерського рівня вищої освіти;

- розширення програм міжнародного обміну учасників освітнього процесу.

\section{Список використаних джерел і літератури:}

Класифбікатор профбесій ДК 003:2010: Національний класифбікатор Украйни. (2010). Взято з https://zakon.rada.gov.ua/rada/show/va327609-10 [in Ukrainian].

Кремень, В. Г. (Ред.). (2014). Розроблення освітніх програм: метод. реком. Київ: ДП «НВЦ «Пріоритети» [in Ukrainian].

Про вищу освіту: Закон України від 1.07.2014 p. № 1556-VII. $\quad$ (2014). Взято 3 https://zakon.rada.gov.ua/laws/show/1556-18 [in Ukrainian].

Про затвердження переліку галузей знань і спеціальностей, за якими здійснюеться підготовка здобувачів вищої освіти: Постанова Кабінету Міністрів України від 29.04.2015 р. № 266. (2015). Взято 3 https://zakon.rada.gov.ua/laws/show/ru/266-2015-\%D0\%BF [in Ukrainian].

Про затвердження переліку предметних спеціальностей спеціальності 014 "Середня освіта (за предлетними спеціальностяли)", за якими здійснюеться формування і розмішення державного замовлення та поєднання спеціальностей (предметних спеціальностей) в системі підготовки педагогічних кадрів: Наказ Міністерства освіти і науки України від 12.05.2016 p. № 506. (2016). Взято з http://zakon5.rada.gov.ua/ laws/show/z0798-16 [in Ukrainian].

Про особливості фбормування навчальних планів на 2015/2016 навчальний рік: Наказ Міністерства освіти і науки України від 26.01.2015 p. № 47. (2015). Взято з http://ru.osvita.ua/legislation/Vishya_osvita/46385/ [in Ukrainian].

Karta nauczyciela po zmianach z 6 grudnia 2007 r. (2008). Poznan: Oficyna Ekonomiczna Wydawnictwa. Zaczerpnięte z http://prawo.sejm.gov.pl/isap.nsf/ download.xsp/WDU20072471821/T/D20071821L.pdf [in Polish].

Laska, E. I. (2007). Edukacja nauczycieli wobec przemian szkoly. Rzeszow: WURZ [in Polish].

\section{References:}

Klasyfikator profesii DK 003:2010: Natsionalnyi klasyfikator Ukrainy [Classifier of Professions DK 003:2010: National Classifier of Ukraine]. (2010). Retrieved from https://zakon.rada.gov.ua/rada/show/ va327609-10 [in Ukrainian].

Kremen, V. H. (2014). Rozroblennia osvitnikh prohram: metodychni rekomendatsii [Development of Educational Programs: Guidelines]. Kyiv: DP «NVTs «Priorytety» [in Ukrainian].

Pro vyshchu osvitu [On Higher Education]: Zakon Ukrainy vid 1.07.2014 p. № 1556-VII. (2014). Retrieved from https://zakon.rada.gov.ua/laws/show/1556-18 [in Ukrainian].

Pro zatverdzhennia pereliku haluzei znan $i$ spetsialnostei, za yakymy zdiisniuietsia pidhotovka zdobuvachiv vyshchoi osvity [About the Statement of the List of Branches of Knowledge and Specialties on which Training of Applicants of Higher Education is Carried out]: Postanova Kabinetu Ministriv Ukrainy vid 29.04.2015 r. № 266. (2015). Retrieved from https://zakon.rada.gov.ua/laws/show/ru/266-2015-\%D0\%BF [in Ukrainian].

Pro zatverdzhennia Pereliku predmetnykh spetsialnostei spetsialnosti 014 "Serednia osvita (za predmetnymy spetsialnostiamy)", za yakymy zdiisniuietsia formuvannia $i$ rozmishchennia derzhavnoho zamovlennia ta poiednannia spetsialnostei (predmetnykh spetsialnostei) v systemi pidhotovky pedahohichnykh kadriv [About the Statement of the List of Subject Specialties of a Specialty 014 «Secondary Education (on Subject Specialties)» on which Formation and Placement of the State Order and a Combination of Specialties (Subject Specialties) in System of Training of Pedagogical Shots is Carried out]: Nakaz Ministerstva osvity i nauky Ukrainy vid 12.05 .2016 p. № 506. (2016). Retrieved from http://zakon5.rada.gov.ua/ laws/show/z0798-16 [in Ukrainian].

Pro osoblyvosti formuvannia navchalnykh planiv na 2015/2016 navchalnyi rik [On the Peculiarities of the Formation of Curricula for the 2015/2016 Academic Year]: Nakaz Ministerstva osvity i nauky Ukrainy vid 26.01.2015 p. № 47. (2015). Retrieved from http://ru.osvita.ua/legislation/Vishya_osvita/46385/ [in Ukrainian].

Karta nauczyciela po zmianach z 6 grudnia 2007 r. [Teacher Map, Modified December 6, 2007]. (2008). Poznan: Vydavnytstvo Ekonomichnyi ofis $\quad$ Retrieved from http://prawo.sejm.gov.pl/isap.nsf/download.xsp/WDU20072471821/T/D20071821L.pdf [in Polish].

Laska, E. I. (2007). Edukacja nauczycieli wobec przemian szkoly [Teacher Education in the Context of School Changes]. Zheshov: WURZ [in Polish]. 
Дата надходження статті: «09» квітня 2020 р.

Стаття прийнята до друку: «20» травня 2020 р.

Білецька Галина - професор кафедри екології та біологічної освіти Хмельницького національного університету, доктор педагогічних наук, доцент

Biletska Halyna - Professor of the Department of Ecology and Biological Education of Khmelnytskyi National University, Doctor of Pedagogical Sciences, Associate Professor

Матеюк Олеся - доцент кафедри екології та біологічної освіти Хмельницького національного університету, кандидат педагогічних наук, доцент

Mateyuk Olesia - Assistant Professor of the Department of Ecology and Biological Education of Khmelnytskyi National University, Candidate of Pedagogical Sciences, Associate Professor

\section{Цитуйте ию статтю як:}

Білецька, Г., \& Матеюк, О. (2020). Порівняльний аналіз підготовки майбутніх учителів біології в університетах України і Польщі. Педагогічний дискурс, 28, 23-31. doi: 10.31475/ped.dys.2020.28.03.

\section{Cite this article as:}

Biletska, H., \& Mateyuk, O. (2020). Comparative Analysis of the Training of Future Biology Teachers at the Universities of Ukraine and Poland. Pedagogical Discourse, 28, 23-31. doi: 10.31475/ped.dys.2020.28.03. 